\title{
Pelatihan Penyusunan Wacana Persuasif dan Promotif Melalui Media Sosial untuk Branding Desa Wisata Kleco, Samigaluh, Kulon Progo
}

\author{
Novi Siti Kussuji Indrastuti \\ Prodi Bahasa dan Sastra Indonesia, Fakultas Ilmu Budaya, Universitas Gadjah Mada \\ Pos-el: novi_indrastuti@ugm.ac.id
}

Tim Pengabdian Masyarakat

Pujiharto, Sugihastuti, Ariyanto, Asef Saeful Anwar, Rakhmat Soleh, Ridha Mashudi

Wibowo, Rudi Ekasiswanto, Sunarso, Umi Mujawazah

\begin{abstract}
In the industrial era 4.0 internet media was put forward for everything. Therefore, at the Kleco Peak in Purwoharjo Village, Samigaluh District, Kulon Progo Regency, which is one of the tourist villages in the Menoreh Mountains region, need effective online media promotion to inform and promote the potential of their village. Nevertheless, the number of human or community resources capable of creating and operating online promotional media in the region is still limited. Therefore, the Indonesian Language and Literature Study Program, Faculty of Cultural Sciences UGM held training on the preparation of persuasive and promotive discourse through social media for branding of Kleco Village, Samigaluh, Kulon Progo. In this training methods were used for presentation, discussion, question and answer, practice and participation, and evaluation. The material presented in this training includes the promotion of tourism through social media, marketing the potentials of the Peak Kleco through photos on social media and persuasive-promotive discourse on social media for the Peak Kleco tourism branding.
\end{abstract}

Keywords: Discourse; promotive; social media; branding; tourism

\begin{abstract}
Abstrak
Pada era industri 4.0 dikedepankan media internet untuk segala. Oleh karena itu, di Puncak Kleco yang berada di Desa Purwoharjo, Kecamatan Samigaluh, Kabupaten Kulon Progo, yang termasuk salah satu desa wisata di kawasan Pegunungan Menoreh sangat diperlukan media promosi yang efektif dalam bentuk daring untuk menginformasikan dan mempromosikan potensi desa mereka. Meskipun demikian, sumber daya manusia atau masyarakat yang mampu menciptakan dan mengoperasikan media promosi dalam bentuk daring di kawasan itu masih terbatas jumlahnya. Oleh karena itu, Program Studi Bahasa dan Sastra Indonesia, Fakultas Ilmu Budaya UGM mengadakan pelatihan penyusunan wacana persuasif dan promotif melalui media sosial untuk branding Desa Kleco, Samigaluh, Kulon Progo. Dalam pelatihan ini dipergunakan metode presentasi; diskusi dan tanya jawab; praktik dan partisipatif; serta evaluasi. Materi yang dipaparkan dalam pelatihan ini meliputi promosi wisata melalui media sosial, memasarkan objek wisata Puncak Kleco melalui foto di media sosial, dan wacana persuasif serta promotif di media sosial untuk branding wisata Puncak Kleco.
\end{abstract}

Kata kunci: Wacana; promotif; media sosial; branding; wisata 


\section{Pendahuluan}

\section{Latar Belakang}

Menyusun wacana merupakan salah satu cara dan bentuk pencapaian intelektual setiap orang. Dengan menulis wacana, gagasan dan keinginan dapat digambarkan dan disebarluaskan kepada khalayak umum. Kemauan, kemampuan, dan kegemaran menulis perlu dipupuk sejak awal, khususnya dalam kehidupan bermasyarakat.

Kegiatan menulis wacana dalam masyarakat dapat menjadi kegiatan yang bermanfaat apabila diolah dengan baik. Memang telah ada sejumlah program pelatihan penulisan untuk masyarakat yang diadakan oleh lembaga pendidikan, tetapi hampir semua program itu mengacu pada pelatihan penulisan ilmiah. Belum banyak pelatihan kepada masyarakat untuk menulis wacana persuasif dan promotif, padahal kemampuan menulis yang bersifat persuasif dan promotif bermanfaat bagi kelangsungan kehidupan bermasyarakat. Kemampuan kreatif yang dimiliki masyarakat akan bermanfaat untuk pembangunan sekitar. Misalnya, dengan kemampuan menulis wacana persuasif dan promotif, masyarakat dapat membuat wacana untuk mempromosikan desa mereka sehingga banyak wisatawan yang tertarik untuk berkunjung ke desa tersebut. Wacana tersebut bisa disebar melalui media sosial dan media digital lain yang marak digunakan pada era industri 4.0 saat ini. Perkembangan teknologi informasi, teknologi, dan komunikasi yang terus berkembang menyebabkan jumlah pengguna internet semakin meningkat setiap tahunnya di Indonesia, bahkan di seluruh dunia.

Desa Kleco sebagai 'desa wisata' perlu diimbangi dengan kemampuan masyarakat yang terampil menulis wacana persuasif dan promotif. Dengan demikian, Desa Kleco bisa semakin berkembang dan dikenal. Masyarakat Desa Kleco, khususnya para anggota karang taruna, menjadi sasaran utama dalam kegiatan ini. Mereka diasumsikan lebih akrab dengan kemajuan teknologi dan media sosial dalam kehidupan keseharian mereka. Selain itu, para pemuda merupakan ujung tombak kemajuan Desa Wisata Kleco. Saat ini, kemampuan menulis persuasif dan promotif untuk pemasaran desa mereka masih kurang. Hal ini dapat terlihat dari unggahan foto di Instagram mereka yang minim takarir gambar (caption), padahal takarir gambar dapat memberikan kesan mengenai objek yang akan dipasarkan dan dapat membuat orang-orang tertarik untuk mengunjungi Desa Wisata Kleco. Lokasi yang cukup jauh dari pusat kota membuat sebagian besar masyarakatnya kurang melek teknologi sehingga mereka kurang dapat mengelola media sosial untuk mempromosikan desa wisata mereka dengan baik.

Sehubungan dengan kondisi tersebut, Program Studi Bahasa dan Sastra Indonesia, Fakultas Ilmu Budaya UGM terdorong untuk mengadakan pelatihan penyusunan wacana persuasif dan promotif melalui media sosial untuk branding Desa Kleco, Samigaluh, Kulon Progo. Dipilihnya Desa Kleco, Samigaluh, Kulon Progo didasarkan oleh dua hal. Pertama, permintaan dari mereka akan adanya kegiatan ini untuk menambah wawasan bagi masyarakat desa. Kedua, membangun relasi baru dalam rangka pengabdian kepada masyarakat oleh Program Studi Bahasa dan Sastra Indonesia.

Dalam kegiatan tersebut, peserta akan diberikan materi-materi penulisan wacana persuasif dan promotif melalui media sosial. Materi akan disampaikan oleh narasumber yang berkompeten dalam bidangnya. Setelah diberikan materi terkait, peserta akan diberikan kesempatan untuk mempraktikkan materi tersebut dengan pendampingan 
dari dosen-dosen Prodi Bahasa dan Sastra Indonesia. Setelah itu, dilaksanakan kegiatan evaluasi.

Setelah program pelatihan ini berakhir, peserta diminta untuk membuat materi dengan menggunakan wacana persuasif dan promotif yang disertai dengan ilustrasi foto, kemudian diunggah ke media sosial. Media sosial adalah platform media yang fokus pada eksistensi pengguna yang memfasilitasi mereka dalam beraktivitas maupun berkolaborasi. Oleh karena itu, media sosial dapat dilihat sebagai medium (fasilitator) daring yang menguatkan hubungan antarpengguna sekaligus sebagai sebuah ikatan sosial (Atiko dkk., 2016:381).

Lokasi dan tempat penyelenggaraan kegiatan ini terletak di Puncak Kleco yang berada di Dusun Purwoharjo, Kecamatan Samigaluh, Kulon Progo. Lokasi ini dipilih karena termasuk salah satu desa yang menjadi sasaran terwujudnya desa wisata di kawasan Pegunungan Menoreh. Dengan adanya bandara baru di Yogyakarta, yakni Yogyakarta International Airport (YIA), perlu dikembangkan wisata Bukit Menoreh berbasis budaya, mengingat kawasan Menoreh merupakan jalur alternatif menuju Candi Borobudur. Dengan demikian, diperlukan sarana informasi, baik berbentuk cetak maupun daring. Oleh karena itu, diperlukan pelatihan penyusunan wacana persuasif dan promotif guna memperkenalkan potensi wisata yang dimiliki dengan dukungan foto dan video.

\section{Masalab}

Pada era industri 4.0, media internet diutamakan untuk segala aktivitas. Oleh karena itu, di Puncak Kleco yang berada di Dusun Purwoharjo, Kecamatan Samigaluh, Kabupaten Kulon Progo, yang termasuk salah satu desa wisata di kawasan Pegunungan Menoreh sangat diperlukan media promosi yang efektif dalam bentuk daring untuk menginformasikan potensi desa mereka. Meskipun demikian, sumber daya manusia atau masyarakat yang mampu menciptakan dan mengoperasikan media promosi dalam bentuk daring di kawasan itu masih terbatas jumlahnya.

\section{Tujuan}

Pelatihan penulisan wacana persuasif dan promotif bertujuan untuk meningkatkan minat dan kemampuan peserta dalam menulis wacana persuasif dan promotif beserta pengimplementasiannya guna mempromosikan desa mereka di media sosial. Di samping itu, Program Studi Bahasa dan Sastra Indonesia juga melakukan monitoring dan evaluasi terkait materi serta pendampingan yang telah dilaksanakan sebelumnya. Hal tersebut dilakukan untuk mengetahui seberapa jauh peserta memahami dan dapat mempraktikkan materi yang disampaikan.

\section{Pedekatan Pelaksanaan Program}

Dalam kegiatan "Pelatihan Penyusunan Wacana Persuasif dan Promotif melalui media sosial untuk branding Desa Wisata Kleco, Samigaluh, Kulon Progo" ini digunakan beberapa metode berikut.

\section{Metode Presentasi}

Dalam penyampaian persentasi di depan peserta, para narasumber menggunakan metode 
presentasi ekstemporan. Metode ini mampu menciptakan interaksi yang baik antara pembicara dan para peserta. Materi presentasi juga lebih terjaga karena menggunakan tayangan yang merupakan semacam acuan, yang memuat ide-ide pokok materi yang disampaikan oleh para narasumber. Di samping itu, pada saat menyampaikan materi, para narasumber juga memanfaatkan tayangan yang berupa foto-foto dan gambargambar. Dengan didukung oleh penggunaan media visual tersebut, materi akan lebih mudah dipahami dan menarik.

\section{Metode Diskusi dan Tanya Jawab}

Setelah narasumber selesai memaparkan materi presentasi, moderator membuka kesempatan bagi para peserta untuk melakukan diskusi dan tanya jawab. Dengan demikian, metode ini memberikan kesempatan bagi seluruh peserta untuk berpartisipasi aktif.

\section{Metode Praktik dan Partisipatif}

Setelah acara tanya-jawab selesai, para peserta dibagi menjadi beberapa kelompok. Masing-masing kelompok didampingi oleh $1-2$ dosen. Dalam diskusi kelompok tersebut, peserta diminta untuk berpartisipasi aktif dan praktik menyusun wacana promosi yang persuasif dengan menggunakan foto salah satu lokasi di Kleco sebagai sarana pemantik. Selanjutnya, wacana hasil diskusi anggota kelompok yang telah dibuat disampaikan oleh masing-masing wakil kelompok untuk kemudian dibahas oleh para narasumber. Narasumber kemudian memberikan umpan balik, evaluasi, dan masukan untuk penyempurnaan wacana yang dihasilkan dari aktivitas pengembangan wacana promosi tersebut.

\section{Metode Evaluasi}

Kegiatan pengabdian di Puncak Kleco ini dilakukan dengan mengadakan kunjungan ke lokasi sebanyak dua kali. Kunjungan pertama digunakan untuk menyampaikan materi, praktik, dan memberikan evaluasi secara singkat terhadap hasil kerja praktik yang dilakukan. Setelah itu, diberikan tugas kepada para peserta untuk memasang foto dan membuat wacana promosi persuasif yang selanjutnya harus diunggah melalui media sosial. Tim kegiatan Pengabdian kepada Masyarakat Program Studi Bahasa dan Sastra Indonesia FIB UGM memantau hasil-hasil tulisan yang telah diunggah oleh para peserta melalui media sosial. Dengan kata lain, di sini dilakukan monitoring jarak jauh. Wacana promosi yang telah diunggah oleh para peserta tersebut dikompilasi. Pada kunjungan kedua ke lokasi, tim Pengabdian kepada Masyarakat melakukan evaluasi terhadap data yang berupa kompilasi hasil karya peserta yang telah diunggah melalui media sosial. Peserta diajak berdiskusi dan diberi masukan guna penyempurnaan penyusunan wacana promosi tersebut.

\section{Pelaksanaan Program}

Dalam kegiatan Pengabdian kepada Masyarakat ini, ditampilkan tiga orang narasumber. Narasumber pertama adalah akademisi yang berkompeten di bidang penyusunan wacana promosi dengan bahasa yang komunikatif atau bahasa gaul. Narasumber kedua adalah 
praktisi yang juga merupakan alumni Program Studi Bahasa dan Sastra Indonesia FIB UGM yang berkompeten di bidang penulisan kreatif. Untuk dapat menyusun wacana promosi yang persuasif di media sosial diperlukan kemampuan menulis kreatif. Narasumber ketiga adalah praktisi di bidang fotografi. Kemampuan memfoto dan strategi pemilihan objek foto sangat diperlukan sebagai pendukung wacana untuk mempromosikan desa wisata. Ketiga narasumber tersebut memaparkan materi tentang promosi wisata melalui media sosial, memasarkan objek wisata Puncak Kleco melalui foto di media sosial, dan wacana persuasif serta promotif di media sosial untuk branding wisata Puncak Kleco. Ketiga materi tersebut diuraikan satu per satu di bawah ini.

\section{Promosi Wisata melalui Media Sosial}

Sebelum menyusun wacana promosi harus diketahui dan ditetapkan terlebih dahulu tujuan promosi. Menurut Swastha (2001:353), tujuan promosi adalah:

- memodifikasi tingkah laku,

- memberi tahu,

- membujuk, dan

- mengingatkan.

Untuk dapat menyusun wacana promosi yang persuasif di media sosial diperlukan pemahaman tentang langkah-langkah penciptaan promosi di media sosial. Cara menciptakan promosi melalui media sosial adalah sebagai berikut.

a) Penciptaan Konten

Penciptaan konten yang dilakukan difokuskan pada wacana yang bertitik tolak dari aspek visual, yakni foto dan video sehingga diperlukan koleksi foto-foto maupun video yang dapat diperoleh melalui berbagai cara. Misalnya, stok foto yang sudah dimiliki oleh warga Kleco menjadikan masyarakat seputar Puncak Kleco sebagai fotografer sehingga terus dapat memperbanyak stok foto yang bisa diunggah ke media sosial, memperbanyak blogger dalam masyarakat di kawasan desa wisata ini, mengunggah ulang (repost) foto dan video dari video atau foto para wisatawan terpilih yang pernah berkunjung ke Kleco. Untuk poin yang terakhir, perlu dimintakan izin kepada pemilik foto tersebut.

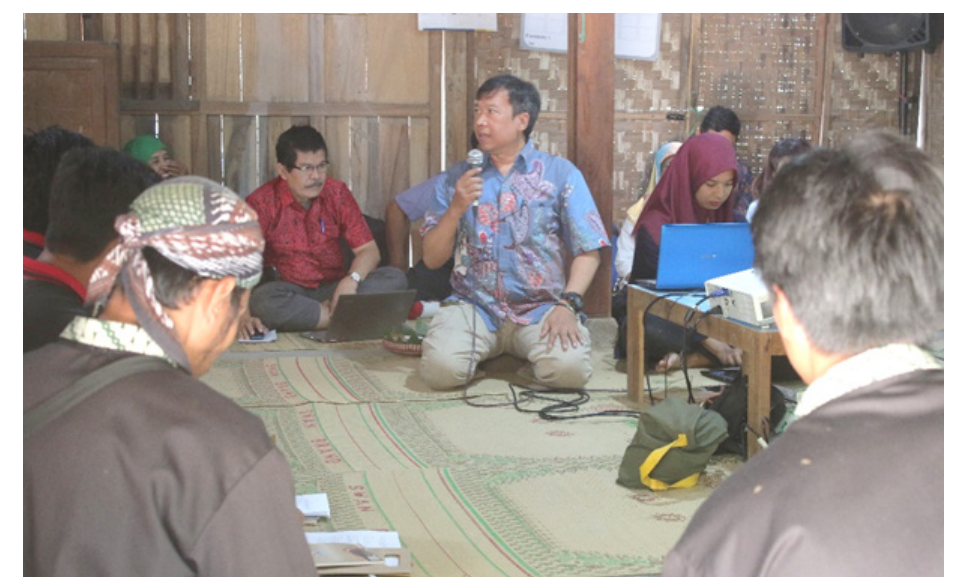

Gambar 1. Penyampaian Materi tentang Cara Menciptakan Promosi melalui Media Sosial 


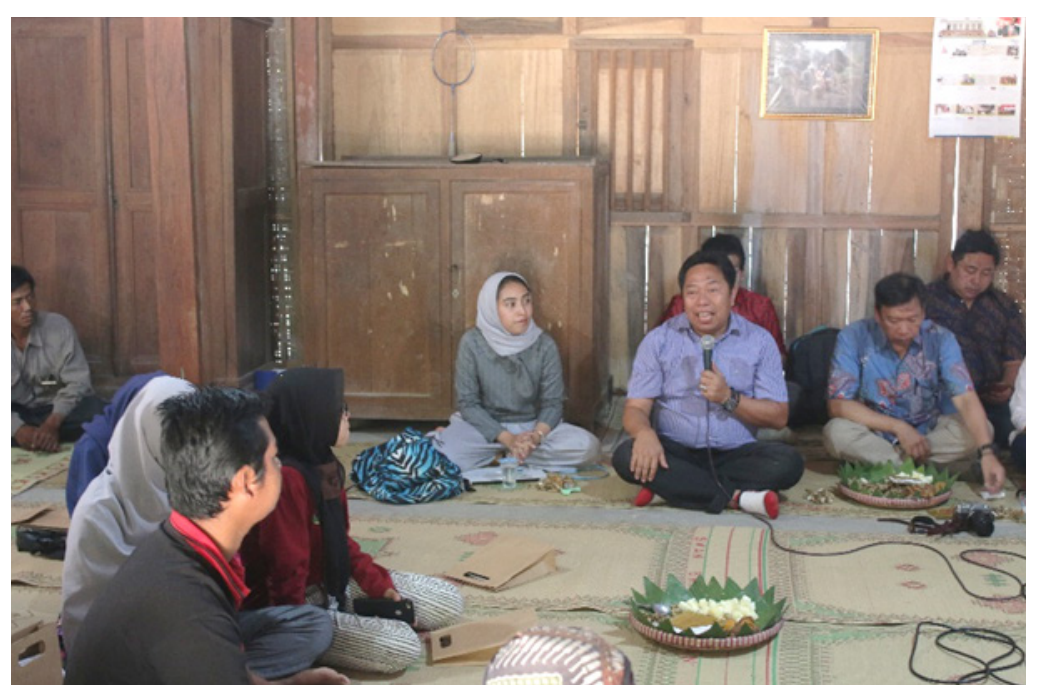

Gambar 2. Penyampaian Materi Fotografi

b) Penentuan Platform

Dalam penentuan platform media sosial yang digunakan sebagai media promosi perlu diperhatikan mengenai hal-hal yang saat ini sedang disukai oleh masyarakat yang menjadi target pemasaran wisata Puncak Kleco, seperti situs web, Instagram, Facebook, Twitter, dan Google Plus yang dinilai memilik potensi yang cukup besar untuk mempromosikan pariwisata di kawasan Puncak Kleco.

c) Pola Update

Menentukan jumlah foto yang harus diunggah dalam sehari dan berapa jumlah video yang harus diunggah per minggu. Konten juga dapat diunggah secara spontan.

d) Strategi Penulisan Takarir Gambar

Dalam penulisan takarir gambar, hal yang penting untuk diperhatikan adalah bahwa penyusunan wacana harus menggunakan bahasa promosi yang komunikatif. Hal tersebut ditujukan supaya dapat menciptakan pelibatan para pengguna media sosial. Oleh karena itu, dalam penulisan takarir gambar harus menggunakan fakta-fakta yang menarik mengenai konten yang diunggah dan menulis wacana yang berbentuk pertanyaan karena hal ini merupakan cara yang cukup efektif untuk menciptakan interaksi dengan penggunanya.

\section{Memasarkan Objek Wisata Puncak Kleco melalui Foto di Media Sosial}

Yang membuat sebuah objek wisata, khususnya desa wisata, menjadi cepat dikenal adalah media sosial. Hal tersebut karena orang akan langsung memiliki keinginan untuk datang saat melihat keindahan foto yang bertebaran di media sosial dan beredar melalui telepon genggam. Instagram dan Facebook merupakan jenis media sosial yang berperan besar dalam menarik perhatian orang untuk segera pergi menuju ke tempat yang diunggah dalam kedua media sosial tersebut.

Objek wisata yang sebagian besar mengandalkan pesona alam pasti sangat memerlukan media sosial untuk pemasarannya. Hal tersebut karena setiap orang pasti memiliki keinginan untuk mengabadikan dirinya saat berada di suatu tempat yang 
indah. Objek wisata akan cepat menjadi populer begitu foto-fotonya bertebaran di akun-akun media sosial di telepon genggam, khususnya di kalangan anak-anak muda. Dengan sangat cepat, foto-foto itu akan memancing ketertarikan anak-anak muda lainnya untuk segera pergi menuju tempat wisata tersebut. Kegemaran swafoto yang sedang melanda anak-anak muda bagaikan virus yang tak dapat dikendalikan. Objek wisata itu kemudian akan menjadi viral dan dipenuhi oleh para pengunjung. Oleh karena itu, bagi desa wisata yang ingin memopulerkan diri, media sosial merupakan pilihan yang tepat. Selain menarik karena berurusan dengan foto-foto yang indah, promosi dengan cara ini juga sangat hemat biaya karena tidak diperlukan pembayaran dan ada kebebasan dalam membuat jumlah unggahan. Kekuatan foto memang luar biasa besar. Foto mampu menjelaskan banyak hal. Sebuah foto bisa mewakili banyak kata (Pranowo, 2019).

Di gardu pandang Puncak Kleco tampak pemandangan landscape pegunungan indah yang menjadi poin utama objek wisata ini. Dengan adanya gardu pandang, pengunjung bisa melihat Kota Wates di sebelah selatan, Kota Jogja di sebelah timur, dan Pengunungan Menoreh di sebelah utara. Di Puncak Kleco juga terdapat beberapa spot untuk foto yang instagramable dengan panorama alam yang indah. Di samping itu, di tempat ini juga terdapat spot-spot foto buatan dengan hiasan-hiasan yang menarik. Puncak Kleco juga cocok digunakan untuk mengabadikan momen matahari terbit dan tenggelam.

Promosi akan bertambah pesat apabila para pengelola desa wisata mampu melibatkan para pengunjung untuk memajang foto-foto objek wisata di akun Instagram pengelola. Strategi lain dapat dilakukan dengan cara menyajikan wacana yang bercerita tentang pesona wisata Puncak Kleco melalui situs web atau blog. Hal tersebut karena foto belum dapat menjelaskan beberapa aspek, misalnya mengenai lezatnya rasa kuliner, cara mencapai objek wisata tersebut, dan sebagainya. Situs web dan blog akan dapat mengatasi kelemahan tersebut.

\section{Wacana Persuasif dan Promotif di Media Sosial untuk Branding Wisata Puncak Kleco}

Pada bagian ini dijelaskan tentang wacana persuasif/promosi, media sosial, branding, Desa Wisata Kleco, dan strategi menyusun wacana persuasif di media sosial.

a) Wacana Persuasif

Wacana persuasif atau tulisan persuasif adalah tulisan yang bertujuan memengaruhi dan mendorong pembaca melakukan tindakan yang diinginkan penulis atau pembuatnya. Promosi atau iklan ditulis menggunakan bahasa persuasif.

Contoh:

Ayo ke Desa Kleco! Pemandangannya indah, makanannya enak.

Bandingkan dengan:

Mau piknik yang murah meriah? Mau kuliner enak? Lihat pemandangan bagus?

Kenal desa wisata? Kleco tempatnya! Ayo rame-rame ke Kleco!

(Wulandari, 2019)

Media sosial adalah media daring yang membuat para penggunanya dapat eksis dengan mudah dengan cara mengunggah konten, membagi konten, mengomentari, 
mengkritisi, berdiskusi, dan sebagainya. Kelebihannya adalah, sebagian besar, media ini tidak berbayar. Orang hanya perlu mendaftar dan berpartisipasi dengan anggota lainnya.

b) Branding

Brand adalah merek dari suatu produk. Dalam hal ini, brand-nya adalah Desa Wisata Kleco. Produknya adalah berupa desa wisata seisinya, termasuk kehidupan sosialbudaya masyarakatnya. Branding adalah berbagai komunikasi dan kegiatan yang dilakukan oleh pemilik brand atau pihak lain yang ditugasi untuk membangun dan membesarkan sebuah brand. Branding Desa Wisata Kleco berarti memopulerkan desa wisata ini sehingga semakin banyak wisatawan yang datang berkunjung.

c) Desa Wisata Kleco

Desa Wisata adalah desa yang didesain sebagai tempat wisata dengan mengandalkan beberapa potensi berikut.

1. keindahan alam

2. keterampilan penduduk

3. kebudayaan

Agar dapat dilakukan promosi yang persuasif dan menghasilkan banyak kunjungan wisatawan serta produk desa wisata dapat banyak terjual, perlu dilakukan pemetaan terhadap tiga hal tersebut di atas.

1. keindahan alam Desa Kleco: sawah, fauna, gunung, dan pemandangan alam adalah yang menjadi kekayaan keindahan alam;

2. keterampilan penduduk: membatik, membuat makanan, membuat permainan, kerajinan, dll. adalah yang bisa jadi sarana wisata;

3. kebudayaan: seni pertunjukan dan adat istiadat yang khas dari Desa Wisata Kleco.

d) Strategi Penyusunan Wacana Persuasif di Media Sosial

Penyusunan wacana persuasif berkaitan dengan aktivitas menulis praktis. Dalam menulis praktis, ada beberapa hal yang perlu diperhatikan, yaitu dapat dibaca secara sekilas karena medianya adalah sosial media, memuat tema yang spesifik, singkat, padat, menarik, dan tidak terduga, serta harus tepat dalam menggunakan diksi.

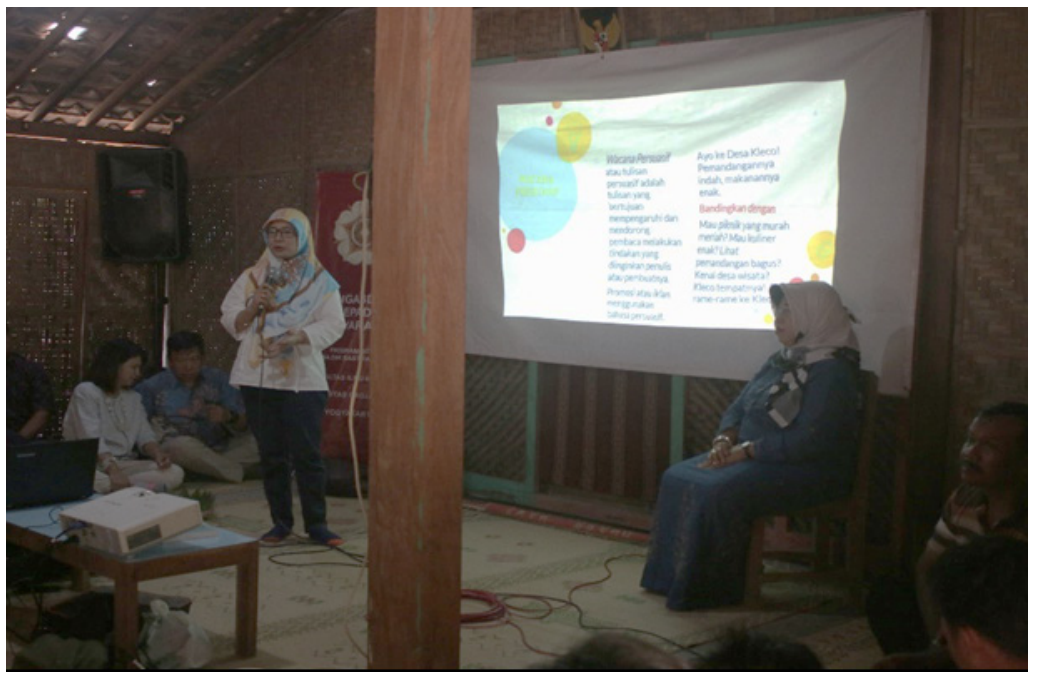

Gambar 3.

Penyampaian Materi oleh Narasumber tentang Wacana Persuasif. 
Dalam pemilihan judul sebaiknya digunakan bahasa yang lugas dan praktis, tidak bertele-tele (to the point), singkat, mudah dipahami, positif, serta mengikuti tren atau kekinian. Misalnya, "Kuliner Khas Kleco" (Wulandari, 2019).

Dalam penulisan wacana promosi pada sosial media sebaiknya digunakan rumus $5 \mathrm{~W}+1 \mathrm{H}$, yakni what, who, where, when, why, dan how. Rumus tersebut dibahas satu per satu di bawah ini.

1. what: apa, menjelaskan sesuatu yang jadi bahasan;

2. who: siapa, menjelaskan siapa pelaku atau pihak yang jadi bahasan;

3. where: di mana, menjelaskan tempat sesuatu atau peristiwa terjadi;

4. when: kapan, menjelaskan waktu terjadinya sesuatu;

5. why: mengapa, menjelaskan sebab-sebab terjadinya sesuatu;

6. how: bagaimana, penjelasan tentang proses atau kejadian dari sesuatu.

Beberapa keuntungan apabila seseorang produktif atau aktif menulis di media sosial dengan tema produk yang di-branding, antara lain:

1. banyak menghasilkan tulisan;

2. banyak publikasi;

3. mutu tulisan terjaga; dan

4. produk menjadi semakin populer.

Dalam aktivitas penulisan wacana di media sosial diperlukan beberapa pendukung, di antaranya:

1. data yang valid;

2. foto-foto yang representatif;

3. bergabung dengan komunitas yang seide;

4. aktif memberikan pendapat dan komentar, tetapi bukan berdebat;

5. tetapkan tema besar dan kecil;

6. miliki materi dan data yang banyak dan update;

7. tentukan secara rutin waktu unggah dan berinteraksi;

8. bergabung di komunitas seide;

9. tidak mudah tersinggung dan lebih tenang.

\section{Penutup}

Kegiatan Pengabdian kepada Masyarakat ini diakhiri dengan penandatanganan naskah Surat Perjanjian Kerja Sama antara FIB UGM dan Desa Purwoharjo, Kecamatan Samigaluh, Kabupaten Kulon Progo. Pihak FIB UGM diwakili oleh Ketua Prodi Bahasa dan Sastra Indonesia, sedangkan dari pihak Desa Purwoharjo diwakili oleh Kepala Desa yang hadir dalam acara tersebut secara langsung.

Kegiatan pengabdian kepada masyarakat ini diharapkan dapat mengembangkan dan meningkatkan kemampuan para peserta dalam menyusun wacana promosi yang persuasif untuk branding kawasan wisata Puncak Kleco. Pada tahun ini dilakukan pelatihan penyusunan wacana promosi yang persuasif untuk branding kawasan wisata Puncak Kleco secara keseluruhan. Pada tahun berikutnya akan lebih difokuskan pada penyusunan wacana promosi yang persuasif untuk potensi produk lokal desa yang khas, yang dapat meningkatkan daya jual kawasan wisata Puncak Kleco. 


\section{Daftar Pustaka}

Atiko, G. dkk. (2016). "Analisis Strategi Promosi Pariwisata melalui Media Sosial oleh Kementerian Pariwisata RI (Studi Deskriptif pada Akun Instagram @Indtravel)”. Jurnal Sosioteknologi, Vol. 15, No. 3, Desember 2016, hlm. 380-389.

Basu, S. dan Irawan. (2001). Manajemen Pemasaran Modern. Yogyakarta: Liberty.

Nasrullah, R. (2015). Media Sosial: Prosedur, Tren, dan Etika. Bandung: Simbiosa Rekatama Media.

Pranowo, H. D. (2019). "Foto sebagai Media Promosi Desa Wisata". Modul Program Pengabdian kepada Masyarakat Prodi Bahasa dan Sastra Indonesia FIB UGM. Yogyakarta.

Wulandari, A. (2019). "Wacana Persuasif dan Promotif melalui Media Sosial untuk Branding Desa Wisata Kleco”. Modul Program Pengabdian kepada Masyarakat Prodi Bahasa dan Sastra Indonesia FIB UGM. Yogyakarta. 